\title{
100-YEAR-OLD HAEMATOLOGICA IMAGES: ACUTE PROMYELOCYTIC LEUKEMIA
}

\section{Carlo L. Balduini}

Ferrata-Storti Foundation, Pavia, Italy

E-mail: CARLO L. BALDUINI, - carlo.balduini@unipv.it

doi:10.3324/haematol.2020.247056

A lthough the association of an exaggerated hemorrhagic syndrome with certain leukemias was described by French authors in $1949,{ }^{1}$ the identification of acute promyelocytic leukemia is unanimously attributed to the Norwegian hematologist LK Hillestad, who, in 1957, described three patients with a special type of acute myeloid leukemia characterized by 'a very rapid fatal course of only a few weeks' duration, a white blood cell picture dominated by promyelocytes, and a severe bleeding tendency due to fibrinolysis and thrombocytopenia'. ${ }^{2} \mathrm{He}$ proposed giving this disease the name that is still used today.

The cover of this issue was taken from a picture (Figure 1) illustrating an article written in German, the dominant language in the scientific world at the beginning of the last century, and published in Haematologica in $1923 .^{3}$ In this paper, entitled 'Über einen Fall akuter Promyelozytenleukämie' (On a case of acute promyelocytic leukemia), the Swiss hematologist Albert Alder described the case of a young woman who developed acute leukemia characterized by the abnormal proliferation of promyelocytes. The most relevant clinical features were an extremely serious hemorrhagic diathesis and the aggressiveness of the disease that led to death within eight weeks. Based on today's knowledge, the cytological characteristics of the leukemic cells shown in the figure suggest that the patient was affected by a microgranular variant of acute promyelocytic leukemia. This paper, therefore, indicates that the identification of acute promyelocytic leukemia occurred far earlier than commonly thought and has to be attributed to Alder, whose name has been so far known for the description of the Alder anomaly and Alder-Reilly granules in the cytoplasm of leukocytes in some forms of mucopolysaccharidosis. ${ }^{4}$
This ancient Haematologica paper is also remarkable for the drug given to the patient: arsenic. This treatment may seem surprising, since arsenic was only recognized in the 1990s as highly effective in the treatment of acute promyelocytic leukemia. ${ }^{5}$ Indeed, arsenic is a very ancient drug and the first information about its use dates back more than 2000 years. ${ }^{6}$ With regards to its antileukemic effect, it was described for the first time in 1878 in one patient with 'leucocythemia' admitted to the Boston City Hospital. ' Since then, arsenic was administered as a primary antileukemic agent for a long time until its replacement by radiation therapy and subsequently by modern chemotherapy. The treatment administered by Adler to his young patient was therefore probably the most commonly used substance at that time for subjects with leukemia.

\section{References}

1. Croizat P, Favre-Gilly J. Les aspects du syndrome hémorrhagiue des leucémies. Sang. 1949;20(7):417-421.

2. Hillestad LK. Acute promyelocytic leukemia. Acta Medical Scandinava. 1957;159(3):189-194.

3. Alder A. Über einen Fall akuter Promyelozytenleukämie. Haematologica. 1923;4:423-427.

4. Alder A. Über konstitutionell bedingte Granulationsveränderungen der Leukocyten. Dtsch Arch Klin Med. 1939;183:372-378.

5. Zhang P, Wang SY, Hu XH. Arsenic trioxide treated 72 cases of acute promyelocytic leukemia. Chin J Hematol. 1996;17(2):58-62.

6. Klaassen CD. Heavy metals and heavy-metal antagonists. In: Hardman JG, Gilman AG, Limbird LE, eds. Goodman \& Gilman's The Pharmacological Basis of Therapeutics. New York: McGraw-Hill, 1996:1649-1672.

7. Cutler EG, Bradford EH. Action of iron, cod-liver oil, and arsenic on the globular richness of the blood. Am J Med Sci. 1878;75:74-84.
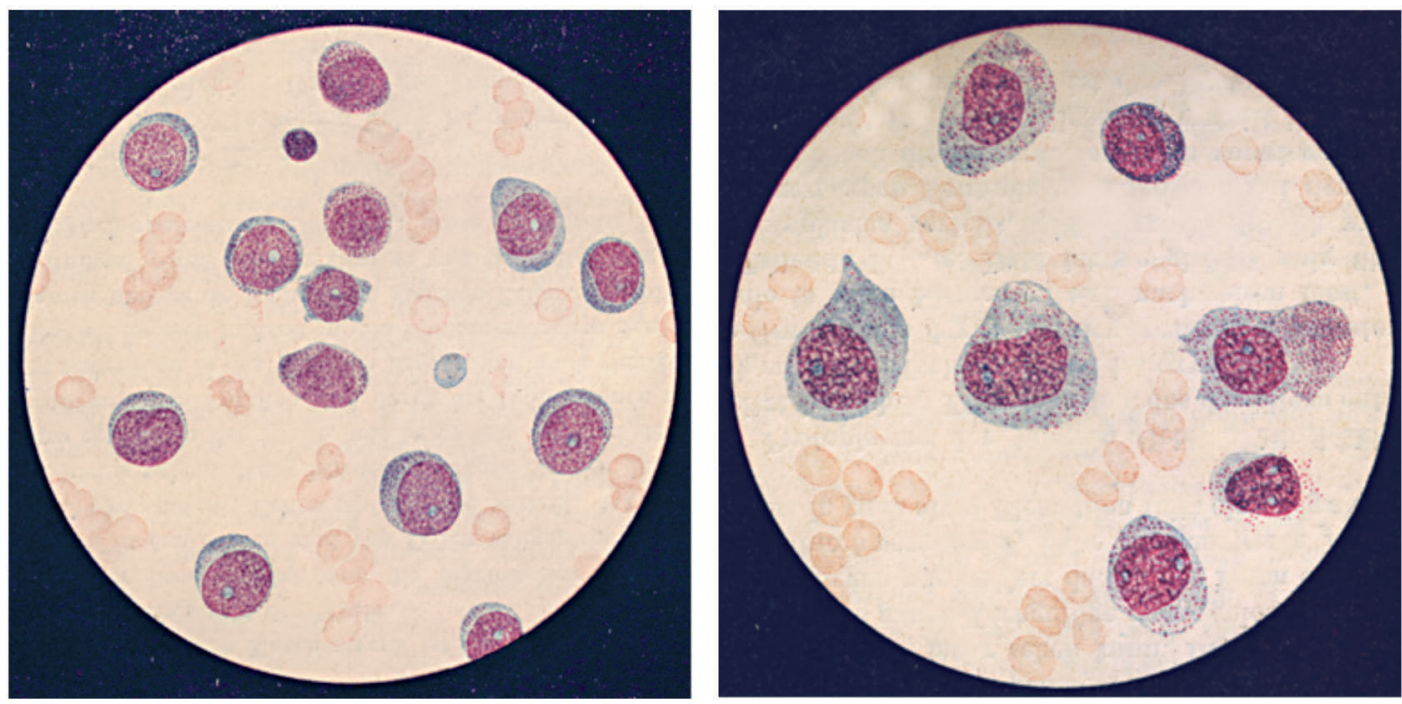

Figure 1. 'Leukemic blood with many promyelocytes and hemoistioblasts (Ferrata cells)'. From the paper 'Über einen Fall akuter Promyelozytenleukämie' published by Alder in Haematologica in 1923. 